\title{
With gratitude from the Editor-in-Chief of the Journal of Plant Research
}

\section{Kouki Hikosaka ${ }^{1}$}

Published online: 13 January 2021

(C) The Botanical Society of Japan 2021
My 4-year term as the Editor-in-Chief of the Journal of Plant Research (JPR), the position I took over from Prof. Ikuo Nishida in 2017 (Nishida 2017; Hikosaka 2017a), will come to an end in March 2021. I am grateful for the honor of having been able to serve the JPR, and I am pleased that the next Editor-in-Chief, Prof. Maki Katsuhara, will start his mission for the 2021-2024 term thereafter.

JPR has exerted great efforts to increase its impact. First, the journal has organized two or three special features annually in these past 4 years, under the category "JPR Symposium", all of which attracted interesting, insightful, and challenging papers: "Expanding the plant non-coding RNA world" (Ohtani 2017) and "Fusion in fertilization: interdisciplinary collaboration among plant and animal scientists" (Yamato and Kuchitsu 2017) in 2017; "Semi-in-vivo developmental biology" (Kondo and Sugano 2018), "Floral development: re-evaluation of its importance" (Iwamoto and Bull-Hereñu 2018), and "Physiological ecology of woody species in response to air pollution and climate changes" (Hoshika and Koike 2018) in 2018; "Regulatory networks in plant growth and development" (Morohashi and Russinova 2019) and "Toward unveiling plant adaptation mechanisms to environmental stresses" (Shibata and Mogami 2019) in 2019; and "Apical stem cell(s): evolutionary basis for 3D body plans in land plants" (Nishihama and Naramoto 2020) and "New aspects of functional plant nuclear architecture" (Sakamoto and Sakamoto 2020) in 2020.

Second, JPR has bestowed awards (the JPR Award) for excellent papers. We have selected two best papers that were published last year and one most-cited paper published 3 years ago (see Hikosaka 2017b, 2018, 2019, and 2020 for the recipients). The best papers were published as open access with the support of grants from the Japanese Society for the Promotion of Science (JSPS).

Kouki Hikosaka

hikosaka@tohoku.ac.jp

1 Graduate School of Life Sciences, Tohoku University, Aoba, Sendai 980-8578, Japan
Third, JPR has published excellent review articles as "Current Topics in Plant Research". Most of them were written by recipients of the Awards of the Botanical Society of Japan (Ebihara and Nitta 2019; Inoue et al. 2018; Miyazawa and Takahashi 2020; Nakamasu and Higaki 2019; Nakamura and Ngo 2020; Nakamura and Noguchi 2020; Takayama et al. 2018; Tsukaya 2019; Yoshida 2018). However, JPR also published review articles from non-recipients (Inada 2017; Kume 2017; Zhang et al. 2020). Some of them were published as open access supported by grants from JSPS.

Fourth, JPR has published two virtual issues: "Alpine and subalpine plant communities: importance of plant growth, reproduction and community assemblage processes for changing environments" (Takahashi 2018) and "Ecology and evolution of pteridophytes in the era of molecular genetics" (Nitta and Ebihara 2019). These issues are collections of JPR papers on specific topics: alpine and subalpine plant ecology and fern studies.

Fifth, JPR created a new category, "Letters", which presents opinions, commentaries, and challenges. The first contribution published in "Letters" appears in this issue (Gounaris 2021).

During these 4 years, JPR has received many papersmore than 500 per year. In 2020, more than 900 papers have been submitted. Our Editors have selected excellent papers, and consequently the quality of papers published in JPR has increased. The impact factor value of the journal has increased from 1.684 (2015) to 1.899 (2016), 2.000 (2017), 2.082 (2918), and 2.185 (2019). I am truly grateful to authors, editors, reviewers, the publisher's staff, and readers, all of whom contributed to the increase in the impact of JPR. In particular, I would like to thank Dr. Masako Mishio in the editorial office, who has devotedly worked to improve the quality of JPR.

We welcome new Editors and Editorial Board members who begin their 4-year terms in January 2021: Drs. Haruhiko Taneda, Koichiro Awai, Yoshitaka Nishiyama, Misato Ohtani, and Kohki Yoshimoto (Editors); and Drs. Tae-Soo Jang, Joel Nitta, Ken Oyama, Yuanhe Yang, Xiaofeng Yin, 
Seisuke Kimura, Hiroyuki Koga, and Jian Zhang (Editorial Board members).

We thank the Editors and Editorial Board members who will be rotating off: Drs. Tomomichi Fujita and Hajime Wada (Editors) and Drs. Yuki Mitsui, Atsushi Ishida, Yasuhiro Utsumi, Stefan de Folter, and Keiko Sugimoto (Editorial Board members). Drs. Hiroyuki Muraoka and Naoto Kawakami also finished their term as Editors but subsequently have re-joined us as Editorial Board members.

We wish you a Very Happy New Year, with the reminder that we welcome submissions of excellent articles in 2021.

Kouki Hikosaka

Editor-in-Chief, Journal of Plant Research

\section{References}

Ebihara A, Nitta JH (2019) An update and reassessment of fern and lycophyte diversity data in the Japanese Archipelago. J Plant Res 132:723-738

Gounaris Y (2021) A proposed free radical explanation for the differential response of long-day and short-day plants to photoperiod. J Plant Res. https://doi.org/10.1007/s10265-020-01234-8

Hikosaka K (2017a) Greetings from the new Editor-in-Chief. J Plant Res 130:417-418

Hikosaka K (2017b) 2017 Awards in the Journal of Plant Research. J Plant Res 130:951-952

Hikosaka K (2018) 2018 Awards in the Journal of Plant Research. J Plant Res 131:725-726

Hikosaka K (2019) 2019 Awards in the Journal of Plant Research. J Plant Res 132:459-460

Hikosaka K (2020) 2020 Awards in the Journal of Plant Research. J Plant Res 133:609-610

Hoshika Y, Koike T (2018) Preface. J Plant Res 131:895-896

Inada N (2017) Plant actin depolymerizing factor: actin microfilament disassembly and more. J Plant Res 130:227-238

Inoue K, Araki T, Endo M (2018) Circadian clock during plant development. J Plant Res 131:59-66

Iwamoto A, Bull-Hereñu K (2018) Floral development: re-evaluation of its importance. J Plant Res 131:365-366

Kondo Y, Sugano SS (2018) Opening new avenues for plant developmental research. J Plant Res 131:3-4

Kume A (2017) Importance of the green color, absorption gradient, and spectral absorption of chloroplasts for the radiative energy balance of leaves. J Plant Res 130:501-514

Miyazawa Y, Takahashi H (2020) Molecular mechanisms mediating root hydrotropism: what we have observed since the rediscovery of hydrotropism. J Plant Res 133:3-14
Morohashi K, Russinova E (2019) Towards a next step of the research of regulatory networks in plant growth and development. J Plant Res 132:155-157

Nakamasu A, Higaki T (2019) Theoretical models for branch formation in plants. J Plant Res 132:325-333

Nakamura Y, Ngo AH (2020) Non-specific phospholipase C (NPC): an emerging class of phospholipase $\mathrm{C}$ in plant growth and development. J Plant Res 133:489-497

Nakamura M, Noguchi K (2020) Tolerant mechanisms to $\mathrm{O}_{2}$ deficiency under submergence conditions in plants. J Plant Res 133:343-371

Nishida I (2017) With gratitude for the Journal of Plant Research. J Plant Res 130:1-2

Nishihama R, Naramoto S (2020) Apical stem cells sustaining prosperous evolution of land plants. J Plant Res 133:279-282

Nitta JH, Ebihara A (2019) Virtual issue: Ecology and evolution of pteridophytes in the era of molecular genetics. J Plant Res 132:719-721

Ohtani M (2017) Expanding the plant non-coding RNA world. J Plant Res 130:3-5

Sakamoto Y, Sakamoto T (2020) Toward an understanding of nuclear substructures beyond their classical functions. J Plant Res 133:447-448

Shibata M, Mogami J (2019) Toward a multifaceted understanding of plants' adaptation mechanisms. J Plant Res 132:299-299

Takahashi K (2018) Virtual issue: Alpine and subalpine plant communities: importance of plant growth, reproduction and community assemblage processes for changing environments. J Plant Res 131:891-894

Takayama K, Crawford DJ, López-Sepúlveda P, Greimler J, Stuessy TF (2018) Factors driving adaptive radiation in plants of oceanic islands: a case study from the Juan Fernández Archipelago. J Plant Res 131:469-485

Tsukaya H (2019) Re-examination of the role of endoreduplication on cell-size control in leaves. J Plant Res 132:571-580

Yamato KY, Kuchitsu K (2017) "Fusion" in fertilization: interdisciplinary collaboration among plant and animal scientists. J Plant Res 130:419-421

Yoshida Y (2018) The cellular machineries responsible for the division of endosymbiotic organelles. J Plant Res 131:727-734

Zhang T, Li C, Li D, Liu Y, Yang X (2020) Roles of YABBY transcription factors in the modulation of morphogenesis, development, and phytohormone and stress responses in plants. J Plant Res 133:751-763

Publisher's Note Springer Nature remains neutral with regard to jurisdictional claims in published maps and institutional affiliations. 